\title{
48. GEOCHEMICAL ANALYSIS OF SAMPLES FROM LEG 48, HOLE 402A BAY OF BISCAY
}

\author{
Daniel B. Pearson, The Superior Oil Company, Houston, Texas \\ and \\ Wallace G. Dow, Getty Oil Company, Houston, Texas
}

\section{INTRODUCTION}

Current interest in continental margins as major energyproducing frontiers makes survey evaluation of unexplored areas of utmost importance. The primary objective of this study is to evaluate the Cretaceous black shale for its thermal history and petroleum-generating potential. A similar issue was addressed in previous studies of the Atlantic margins in Dow $(1978 \mathrm{a}, \mathrm{b})$ for the western Atlantic continental margin and in Pearson and Dow (in press) on the continental margin of the eastern Atlantic. Survey evaluation of unexplored areas can foster broad, regional models of thermal and geologic history, upon which later detailed studies can improve. The present study is intended to fit into the regional model outlined in the three previous studies.

\section{EXPERIMENTAL PROCEDURES}

Sample preparation and analytical procedures for Leg 48 are the same as described for Leg 44 (1978). Similarity of analytical procedures allows direct comparison of sample suites from different studies and minimizes anomalies due to different analytical procedures.

\section{RESULTS}

Dark gray to black laminated and silty shales of upper and lower Aptian age are relatively rich in organic carbon and are rated as marginal to very good in source quality. The kerogen in the three upper Aptian samples is a mixed maceral type with approximately equal amounts of marine and terrestrial components. The preponderance of terrestrial organic matter in the kerogen of the lower Aptian sample indicates that dry gas is its main potential generation product. This shallow section is less than the maturity of significant oil generation $\left(0.6 \% \mathrm{R}_{\mathrm{o}}\right)$ which, by projection, should occur at approximately 1,150 meters below sea bottom. The depth to the top of the wet gas generation zone $\left(0.8 \% \mathrm{R}_{\mathrm{o}}\right)$ is about 1,700 meters. Projection to initial maturities $\left(0.2 \% \mathrm{R}_{\mathrm{o}}\right)$ suggests that approximately 900 meters of section is missing at the upper Aptian-middle Eocene unconformity. All of the analyzed samples contain abundant amounts of two populations of recycled humic matter which were deposited as high volatile $\mathrm{B}$ and $\mathrm{A}$ bituminous rank coals. If the section encountered at Hole 402A (Figure 1) is representative of this part of the Atlantic continental slope, the province as a whole has very little chance of having generated oil or gas.

\section{DISCUSSION}

\section{Organic Carbon and Carbonate Content}

Organic carbon in the upper Aptian section is variable but generally high, ranging from 1.26 to 2.23 weight per cent
(Table 1). The carbonate content of the three upper Aptian samples ranges from 25 to 42 weight per cent. Organic carbon and carbonate contents of the lower Aptian sample are 0.58 and 14 weight per cent, respectively. Based on the organic carbon content, the upper Aptian samples are rated as good to very good in source quality and the lower Aptian is rated marginal. These samples may not be representative of the entire penetrated section because only the darker, supposedly more organic-rich samples were selected in an effort to evaluate possible petroleum source intervals.

\section{Organic Extract}

Extractable organic matter data for a sample from each of the upper and lower Aptian sections are summarized in Tables 2 and 3. Gas chromatograms of the saturate fractions are shown in Figure 2. The extract to organic carbon ratios (Table 3) for both samples are high, but much of the extract comprises NSO and asphaltene components (Table 2) indicating thermal immaturity. The saturate to organic carbon ratios (Table 3 ) are 0.022 and 0.074 for the upper and lower Aptian samples, respectively. These values are also indicative of immature source rocks. The slightly elevated saturate content in the lower Aptian sample, especially in the range of normal saturates from $\mathrm{C}_{21}$ to $\mathrm{C}_{24}$, may be in part due to contamination by drilling-associated lubricants which are compositionally high in this range of compounds (Dow, 1977, 1978).

\section{Kerogen Type}

The kerogens from Hole 402A samples are mixed maceral types with generally predominant amounts of humic organic matter although amorphous organic matter comprises a greater proportion of the kerogen in the upper than in the lower Aptian samples. Based on the relative amounts of humic and amorphous matter, the upper Aptian kerogen is judged to be a wet gas and oil source and the lower Aptian strictly a dry and minor wet gas source (Table 3 ).

The much greater proportion of amorphous matter in the upper as opposed to the lower Aptian may be a function of tectonic change in the terrigenous source area, with proportionately less land-derived material being deposited in the upper than in the lower Aptian. The change in organic matter could also be due to a change to a more reducing environment or to greater marine organic productivity in the upper Aptian.

\section{Kerogen Maturity}

Vitrinite reflectance values and random $R_{0}$ means (Dow, $1978 \mathrm{a}, \mathrm{b})$, are shown on Table 4 . The maturation profile for Hole 402A (Figure 3) shows the profiles for the primary, first cycle kerogen, as well as two recycled kerogen groups. The maturation gradient for the primary kerogen is identical 
402

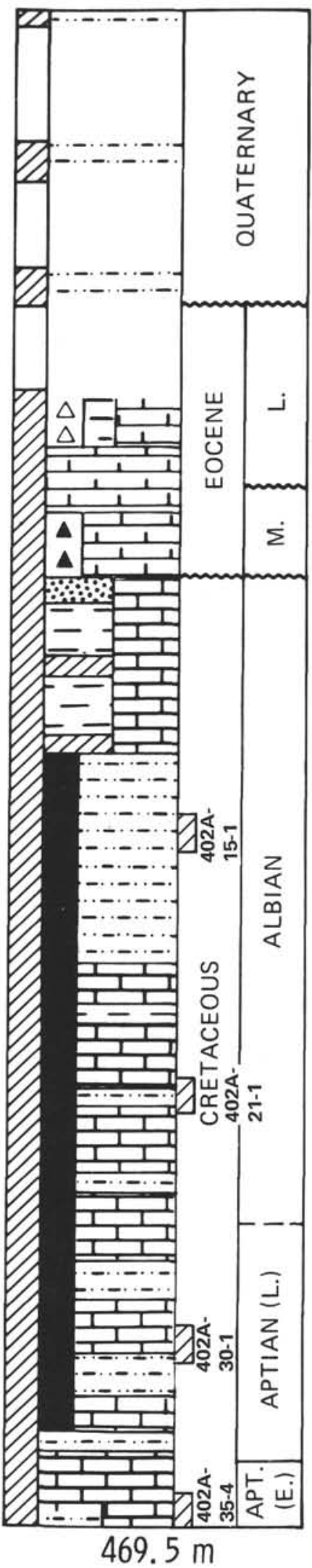

Figure 1. General stratigraphy of Site 402 drilled during Leg 48.
TABLE 1

Organic Carbon Data

\begin{tabular}{|c|c|c|c|c|}
\hline $\begin{array}{c}\text { Sample } \\
\text { (Interval in } \mathrm{cm} \text { ) }\end{array}$ & Age $^{\mathrm{a}}$ & Lithology & $\begin{array}{l}\mathrm{HCl} \text { Sol. } \\
\text { (wt. \%) }\end{array}$ & $\begin{array}{l}\text { Org. C } \\
\text { (wt. \%) }\end{array}$ \\
\hline $402 \mathrm{~A}-13-3,70-75$ & Upper Albian & Black mud sandstone & n.d. & n.d. \\
\hline $402 \mathrm{~A}-15-1,10-14$ & Upper Albian? & $\begin{array}{l}\text { Dark gray-black laminated } \\
\text { silty shale }\end{array}$ & 35.1 & 1.26 \\
\hline $402 \mathrm{~A}-18-1,13-18$ & Upper Albian? & $\begin{array}{l}\text { Dark gray-black laminated } \\
\text { shale }\end{array}$ & n.d. & n.d. \\
\hline $402 \mathrm{~A}-21-1,70-75$ & Albian? & Black laminated shale & 25.0 & 2.23 \\
\hline $402 \mathrm{~A}-24-1,35-41$ & Lower Albian & Black laminated shale & n.d. & n.d. \\
\hline $402 \mathrm{~A}-30-1,0-6$ & Upper Aptian & $\begin{array}{l}\text { Dark gray-brown-black } \\
\text { laminated silty shale; } \\
\text { shale fragments }\end{array}$ & 41.7 & 1.54 \\
\hline $402 \mathrm{~A}-33-1,57-62$ & Upper Aptian & $\begin{array}{l}\text { Light-med gray laminated } \\
\text { shale }\end{array}$ & n.d. & n.d. \\
\hline $402 \AA-35-4,0-5$ & Lower Aptial & $\begin{array}{l}\text { Black-very black laminated } \\
\text { shale }\end{array}$ & 13.9 & 0.58 \\
\hline
\end{tabular}

${ }^{a}$ From Initial Core Description

Note: n.d. $=$ not determined.

TABLE 2

Soxhlet Extraction Data

\begin{tabular}{lcllll}
\hline Sample & Total Extract & \multicolumn{4}{c}{ Per cent Composition } \\
(Interval in cm) & (ppm) & Sat. & Arom. & NSO & Asph. \\
\hline 402A-13-1, 70-75 & n.d. & n.d. & n.d. & n.d. & n.d. \\
402A-15-1, 10-14 & n.d. & n.d. & n.d. & n.d. & n.d. \\
402A-18-1, 13-18 & n.d. & n.d. & n.d. & n.d. & n.d. \\
402A-21-1, 70-75 & 3020 & 16.3 & 5.9 & 36.3 & 43.7 \\
402A-24-1, 35-41 & n.d. & n.d. & n.d. & n.d. & n.d. \\
402A-30-1, 0-6 & n.d. & n.d. & n.d. & n.d. & n.d. \\
402A-33-1, 57-62 & n.d. & n.d. & n.d. & n.d. & n.d. \\
402A-35-4, 0-5 & 3904 & 11.0 & 0.8 & 44.9 & 43.3 \\
\hline
\end{tabular}

Note: n.d. $=$ not determined

TABLE 3

Source Rock Type

\begin{tabular}{|c|c|c|c|c|c|}
\hline & Kerogen & & Extract & & \\
\hline $\begin{array}{c}\text { Sample } \\
\text { (Interval in } \mathrm{cm} \text { ) }\end{array}$ & $\begin{array}{l}\text { Dominant Org. } \\
\text { Matter Type }\end{array}$ & CPI & $\begin{array}{c}\text { Total } \\
\text { Ext/Org C }\end{array}$ & $\begin{array}{c}\text { Total } \\
\text { Sat/Org C }\end{array}$ & $\begin{array}{c}\text { Source } \\
\text { Type }\end{array}$ \\
\hline $402 \mathrm{~A}-13-3,70-75$ & Humic & n.d. & n.d. & n.d. & Wet gas \& oil \\
\hline $402 \mathrm{~A}-15-1,10-14$ & Humic & n.d. & n.d. & n.d. & Wet gas \\
\hline $402 \mathrm{~A}-18-1,13-18$ & Humic & n.d. & n.d. & n.d. & Wet gas \\
\hline $402 \mathrm{~A}-21-1,70-75$ & Humic & 1.40 & 0.135 & 0.022 & Wet gas \& oil \\
\hline $402 \mathrm{~A}-24-1,35-41$ & Humic & n.d. & n.d. & n.d. & Wet \& dry gas \\
\hline $402 \mathrm{~A}-30-1,0-6$ & Humic & n.d. & b,d, & n.d. & Wet gas \& oil \\
\hline $402 \mathrm{~A}-33-1,57-62$ & Humic & n.d. & n.d. & n.d. & Wet \& dry gas \\
\hline $402 \mathrm{~A}-35-4,0-5$ & Humic & 1.28 & 0.673 & 0.074 & $\begin{array}{l}\text { Dry gas \& } \\
\text { wet gas }\end{array}$ \\
\hline
\end{tabular}

Note: n.d. $=$ not determined.

to that from other DSDP sites on the eastern and western margins of the Atlantic (Dow, 1978b; Pearson and Dow, in press). This profile indicates that the penetrated section is thermally immature and that the maturity of initial significant oil generation $\left(0.6 \% \mathrm{R}_{0}\right)$ should occur at approximately 1,150 meters below sea bottom. Wet gas generation $(0.8 \%$ $R_{0}$ ) should occur at about 1,700 meters. Projection of the primary kerogen maturity profile back to a maturity of $0.2 \%$ $\mathrm{R}_{0}$ (the maturity of initially formed vitrinite) indicates approximately 900 meters of section has been lost at the Eocene-Albian unconformity. It is not possible to determine whether the loss occurred entirely at this unconformity or at other later unconformities without analyzing kerogen samples from the Tertiary part of the section. Similar projection of the recycled kerogen profiles to the same relative depth of 

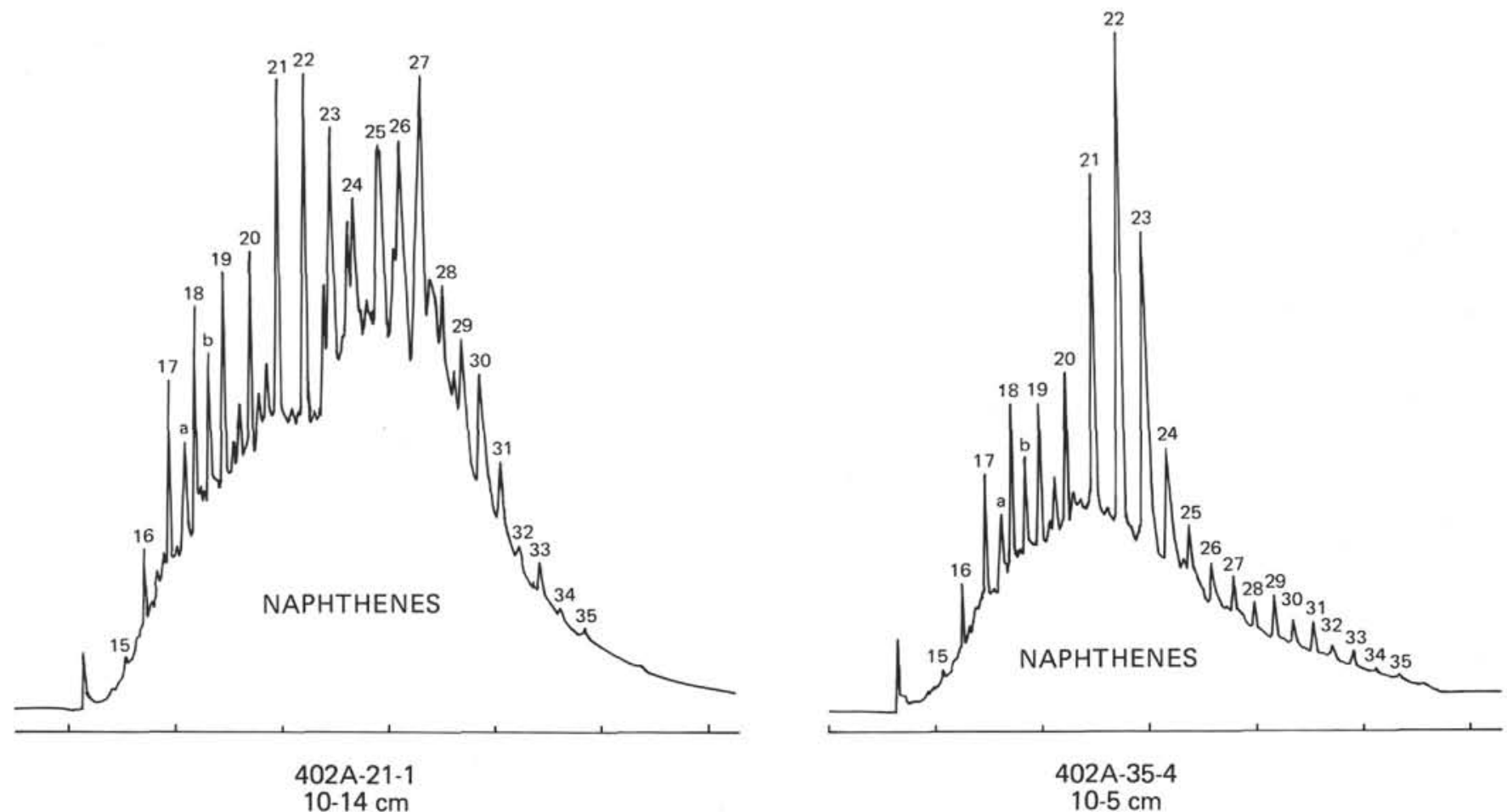

Figure 2. Gas chromatograms of the total saturate fractions separated as in DW a and $b$.

TABLE 4

Vitrinite Reflectance Data

\begin{tabular}{lccc}
\hline $\begin{array}{c}\text { Sample } \\
\text { (Interval in cm) }\end{array}$ & $\begin{array}{c}\text { Maturity } \\
\left(\mathrm{R}_{\mathrm{o}} \%\right)\end{array}$ & $\begin{array}{c}\text { Recycled Maturity }\left(\mathrm{R}_{\mathrm{o}} \%\right) \\
\text { Group 1 }\end{array}$ & Group 2 \\
\hline 402A-13-1, 70-75 & 0.37 & 0.90 & n.p. \\
402A-15-1, 10-14 & 0.38 & 0.93 & 1.25 \\
402A-18-1, 13-18 & 0.36 & 0.93 & n.p. \\
402A-21-1, 70-75 & 0.38 & 0.94 & 1.30 \\
402A-24-1, 35-41 & 0.37 & 0.94 & 1.28 \\
402A-30-1, 0-6 & 0.40 & 0.96 & 1.32 \\
402A-33-1, 57-62 & 0.41 & 0.97 & 1.34 \\
402A-35-4, 0-5 & 0.42 & 0.99 & n.p. \\
\hline
\end{tabular}

Note: n.p. $=$ not present.

$0.2 \% R_{0}$ on the primary profile indicates the approximate maturity of the recycled group at the time of deposition. The two recycled groups were thus deposited at maturities of about $0.64 \%$ and $0.96 \%$ Ro, or high volatile " $\mathrm{B}$ " and "A" bitmunious coals, respectively (Figure 4).

\section{REFERENCES}

Dow, W.G., 1978a. Contact metamorphism of kerogen in sediments from Leg 41: Cape Verde Rise and Basin. In Lancelot,V., Seibold, E., et al., Initial Reports of the Deep Sea Drilling Project, v. 41: Washington (U.S. Government Printing Office), p. 821-824.

, 1978b. Geochemical analysis of samples from Holes 391A and 391C, Leg 44: Blake-Bahama Basin. In Benson, W.E., Sheridan, R.E., et al., Initial Reports of the Deep Sea Drilling Project, v. 44: Washington (U.S. Government Printing Office), p. 625-634.

Pearson, D.B. and Dow, W.G., in press. Geochemical analysis of samples from Holes 397A and 398D, Legs 47A and B.In Ryan, W., von Rad, U., et al., Initial Reports of the Deep Sea Drilling Project, v. 47, Part 2: Washington (U.S. Government Printing Office). 
KEROGEN MATURATION PROFILE

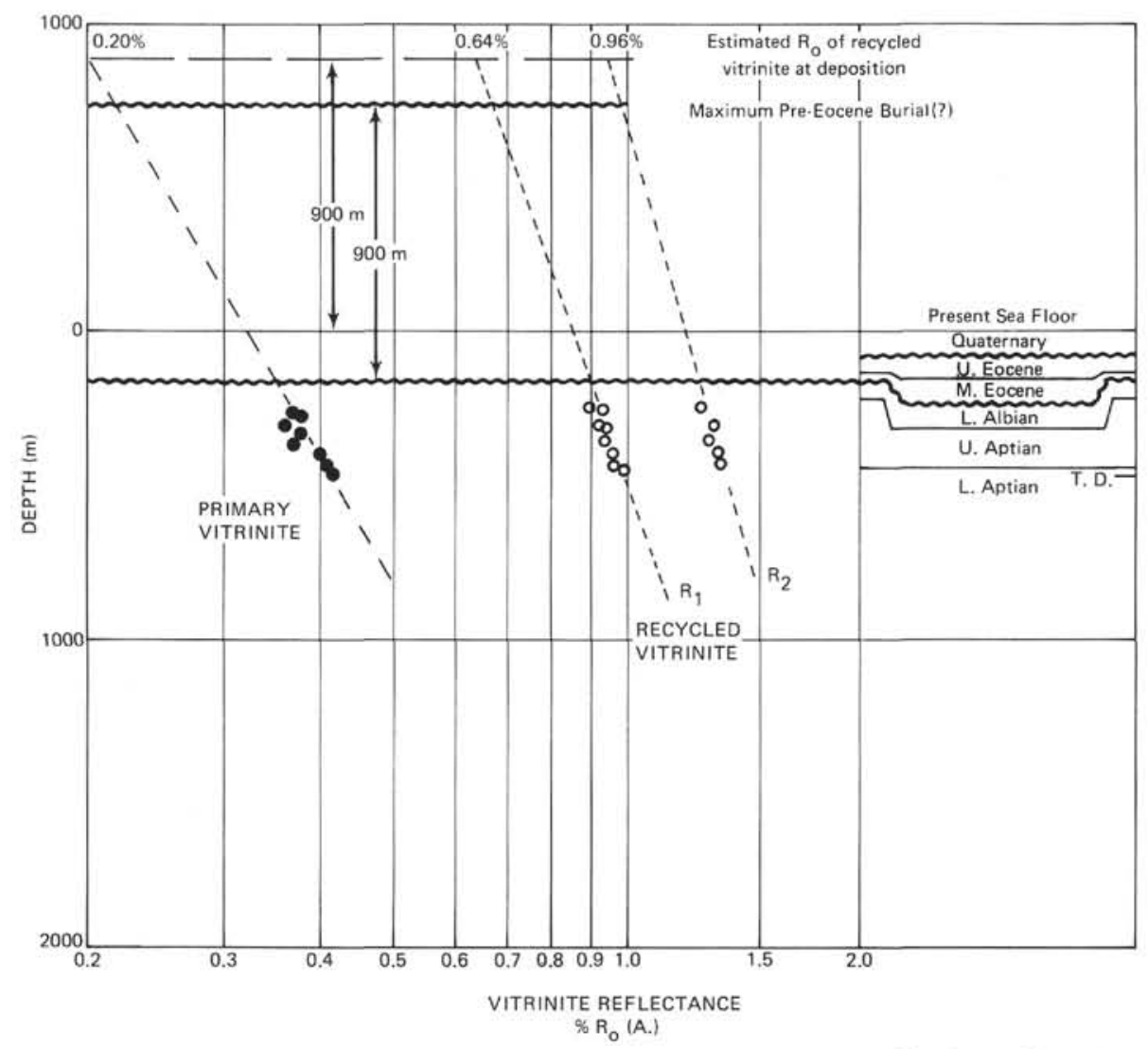

Figure 3. Maturity profile showing primary and recycled vitrinite. Gradient for primary group taken from regional eastern Atlantic continental margin gradient.

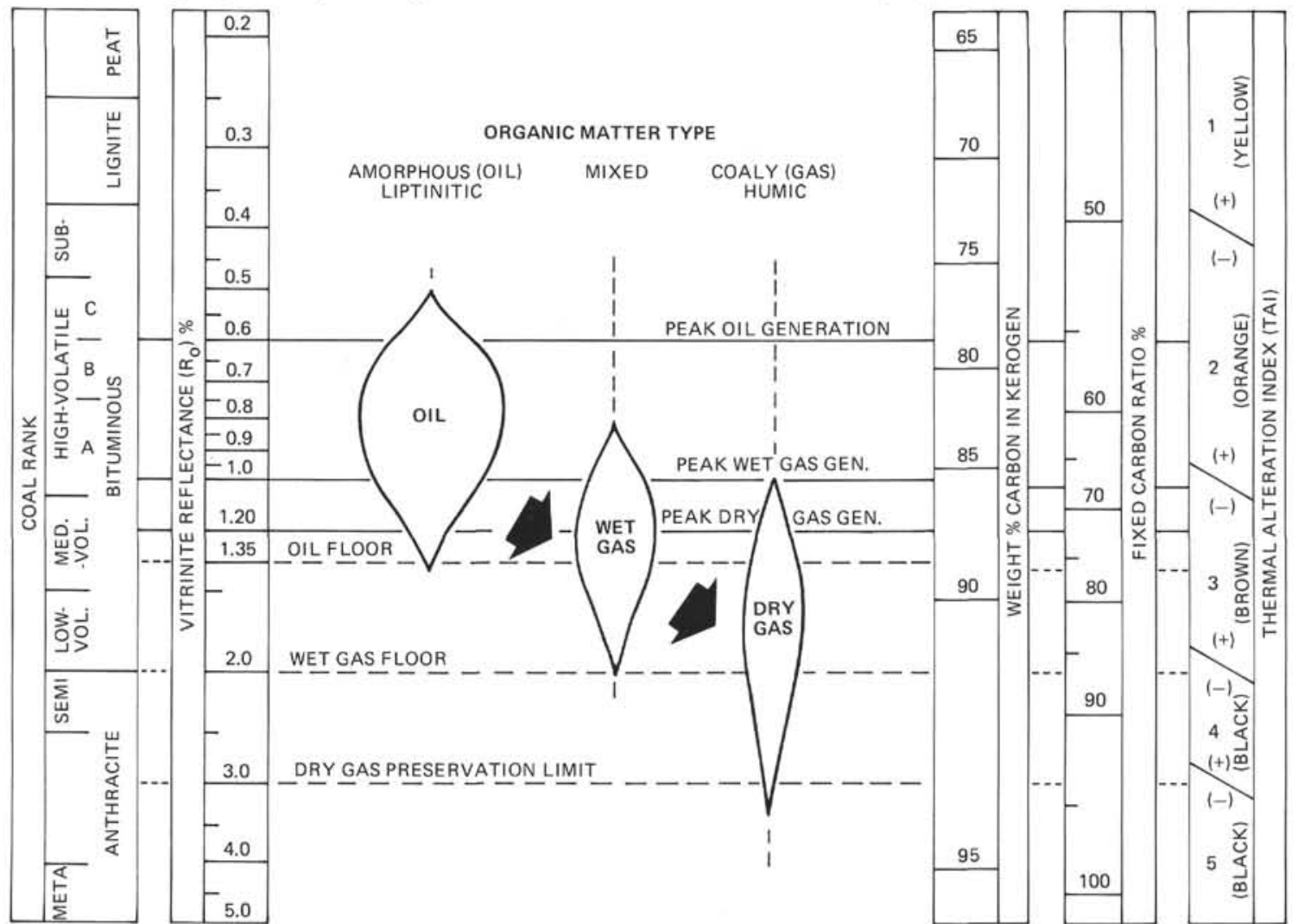

Figure 4. Correlation of the coal rank scale with various maturation indices on the zones of petroleum generation and destruction. 